\title{
The Scheffe's method in the study of mathematical model of the polymeric hydrogels composite structures optimization
}

\author{
Grytsenko O. M. ${ }^{1}$, Pukach P. Ya. ${ }^{1}$, Suberlyak O. V. ${ }^{1}$, Moravskyi V. S. ${ }^{1}$, Kovalchuk R. A. ${ }^{2}$, \\ Berezhnyy B. V. ${ }^{1}$ \\ ${ }^{1}$ Lviv Polytechnic National University, \\ 12 S. Bandera Str., 79013, Lviv, Ukraine \\ ${ }^{2}$ Hetman Petro Sahaidachnyi National Army Academy, \\ 32 Heroes of Maidan Str., 79012, Lviv, Ukraine
}

(Received 18 August 2019; Revised 14 October 2019; Accepted 16 October 2019)

\begin{abstract}
Mathematical modeling of 2-hydroxyethylmethacrylate with polyvinylpyrrolidone copolymerization process according to technological parameters of the exothermic reaction has been carried out by Scheffe's simplex-lattice planning method. Optimization of polymer monomer composition formula has been carried out and the regression equations of the main parameters of exothermic polymerization - gelation time, the duration of the gel effect area, and the maximum temperature of the exotherm have been obtained. Using the mathematical model obtained, the content of the initial composition has been defined. The exothermic effects of such initial composition polymerization provide the optimal technological parameters of metal ions reduction stage during polymerization.
\end{abstract}

Keywords: mathematical modeling, Scheffe's simplex-lattice planning method, optimization of composition formula, metal-filled hydrogels, exothermy.

2000 MSC: 00A71, 62P30

UDC: 678.746

DOI: $10.23939 / \mathrm{mmc} 2019.02 .258$

\section{Introduction}

In connection with the significant complexity of research objects of real technological systems and with a considerable increase of expenses for carrying out the experimental research, a problem of improving the mathematical modeling methods of these systems is actual. Such an improvement of mathematical models and methods contributes to the development of practical qualitative and analytical computational algorithms with the aim, in particular, of designing and optimizing the parameters of physical [1], mechanical [2], social systems [3], etc.

In recent years, approaches to experimentally-static research changed radically. In chemical technologies, in particular, in the technology of polymers synthesis, an experiment is the main source of information. However, usually, the obtaining of experimental data is a process, which needs a lot of material expenses, time, energy, etc. $[4,5]$. Therefore, for modeling chemical and technological processes the mathematical modeling of an experiment is widely used nowadays [6-10]. One of the relevant technological issues is planning and optimization of multicomponent systems [11-13], and also a prediction of characteristics and properties of produced polymers and composites. Quite often, properties of obtained material do not depend on the volume of the initial composition, but on its ingredients content only. Developed methods of optimization provide the use of a mathematical apparatus not only on the stage of analyzing research results but also during their forecast. That gives an opportunity to decrease significantly materials and time consuming for providing the experiment occurring [14,15]. The greatest use was made by Scheffe's simplex-lattice plans [16-18]. The advantage of simplex-lattice plans (SLP) is the possibility to predict the values of properties for multicomponent systems with any composition using the minimum experimental results [17]. 


\section{Statement of the problem}

Nowadays, significant success has been achieved in the development of the new methods [19], optimization of the synthesis conditions [20] and the properties [21,22] of composite metal-filled polymers. This is a prerequisite for creating materials with unique properties for different fields of application [23]. Composite materials based on metal-filled polymer hydrogels have particular importance among these materials $[24,25]$. The uniqueness of such materials is provided by a synergy of properties of the polymer matrix and metal filler [26,27]. Mainly, the choice of the method for obtaining metal-filled hydrogels affects the formation of their complex of properties [28]. A new method of obtaining metalfilled hydrogels based on copolymers 2-hydroxyethyl methacrylate (HEMA) with polyvinylpyrrolidone (PVP) was proposed, which consists in the implementation of polymerization with the simultaneous reduction of metal ions by using an exoeffect of polymerization $[29,30]$. The possibility of obtaining metal-filled hydrogels by polymerization with simultaneous chemical reduction of nickel [29] and argentum [30] ions has been proved. The diverse influence of the initial polymer-monomer composition (PMC) formula on the parameters of the exothermic process was proved that complicates the choice of the ratio of components for synthesis by the experimental method.

At the same time, the development of technology for obtaining metal-filled hydrogels by polymerization method with simultaneously chemical reduction of metal ions suggests the grounding and determination of optimal technological parameters for its realization. One of the important stages of the process is a chemical deposition of metal filler particles. As kinetic investigations of the speed of nickel ions reduction by hypophosphites have shown, the main parameters of the process are the duration of the induction period of reduction $\left(\tau_{\text {i.r. }}\right)$, duration of reduction $\left(\tau_{\text {r.t. }}\right)$, the reduction temperature $\left(T_{r}\right)$ [28]. A start time of gel formation $\left(\tau_{\text {s.f. }}\right)$, a duration of gel effect area $\left(\tau_{\text {d.e. }}\right)$ and the maximum exothermic temperature $\left(T_{\max }\right)[29,30]$ were used for a characteristic of the copolymerization process HEMA with PVP $[26,27] . \tau_{\text {s.f. }}, \tau_{\text {d.e. }}, T_{\max }$ parameters have been taken on the base of thermometric polymerization research $[29,30]$. It needs to choose compositions, which polymerize with the maximum heat liberation, the minimum induction period and with the maximum gel effect area according to the technological features of obtaining metal-filled hydrogels by the proposed method. The kinetic parameters of the polymerization depend on the composition PMC, the content of the solvent and $T_{0}$, what have been shown by the results of what have been shown by the results of thermometric research. The initial temperature of polymerization was taken $T_{\max }=50^{\circ} \mathrm{C}$. At higher initial temperatures, $T_{\max }$ increases to $110-130^{\circ} \mathrm{C}$ with intense boiling of the composition. At the same time, it has been determined that the content of solvent, of HEMA and PVP initial composition has a diverse influence on the parameters of the exothermic process. Experimentally, the optimal combination of the influence factors values could not be figured out (content of the original composition components), which helps to achieve the extremums of all the necessary response functions. Therefore, for research the simultaneous influence of initial composition components on the parameters of exothermic process was used optimization by means of Scheffe's SLP in order to reduce the amount of experimental costs. The effectiveness of using SLP to optimize compositions based on PVP was confirmed in previous works [11,12]. However, all carried out research concerns the establishment of the dependence of "composition-property". The purpose of this work is to implement an optimization of the composition of the original HEMA/PVP $/ \mathrm{H}_{2} \mathrm{O}$ composition and to obtain the dependences of "composition-technological parameters" with the possibility of forecasting the technological conditions for the chemical reduction of metal ions during polymerization.

\section{The method of constructing a multivariate mathematical model}

For mixtures, whose properties depend only on the component ratio, the factor space is a regular $(q-1)$-dimensional simplex [16]. The necessary requirement in the simplex method is to provide a condition fulfillment (1) at each experimental point 


$$
\sum_{i=1}^{q} X_{i}=1,
$$

where $X_{i} \geqslant 0$ is the concentration of the $i$-th component in the composition, $q$ is the number of mixture components.

During the research of the mixtures properties, which depend only on three components, the factor space is represented as an equilateral triangle (Fig. 1). In this case, the ratio is executed:

$$
X_{1}+X_{2}+X_{3}=1 \text {. }
$$

The vertices of the triangle correspond to the pure substances, the sides correspond to the double systems.

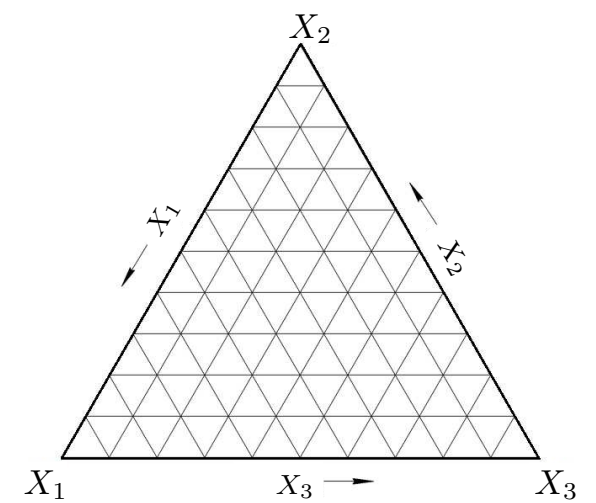

Fig. 1. Triangles for the research of "composition-property" diagrams: $(\boldsymbol{a})$ is concentration triangle; $(\boldsymbol{b})$ is local area of research.

Table 1. The matrix of planning for $\{3,2\}$-lattice.

\begin{tabular}{|c|c|c|c|c|}
\hline No. & $X_{1}$ & $X_{2}$ & $X_{3}$ & $X_{\exp }$ \\
\hline 1 & 1 & 0 & 0 & $y_{1}$ \\
2 & 0 & 1 & 0 & $y_{2}$ \\
3 & 0 & 0 & 1 & $y_{3}$ \\
4 & $1 / 2$ & $1 / 2$ & 0 & $y_{12}$ \\
5 & $1 / 2$ & 0 & $1 / 2$ & $y_{23}$ \\
6 & 0 & $1 / 2$ & $1 / 2$ & $y_{13}$ \\
\hline
\end{tabular}

Scheffe's plans provide an equitable distribution of experimental points for $(q-1)$ is measuring simplex. Experimental points represent $\{q, n\}$ is lattice on the simplex, where $q$ is the number of composition components, $n$ is the degree of polynomial [16]. In this case, the result of the research is a multifactor mathematical model in the form of a polynomial of a given degree. Simplex-lattice plans are saturated plans. There are $(n+1)$ equally placed levels $X_{i}=0,1 / n$, $2 / n, \ldots, 1$ for each component and all possible combinations with the following values of component concentrations are used. Thus, for the quadratic lattice $\{q, 2\}$, which ensures approximation the response surface by polynomials of the second degree, the following levels of each of the factor must be used: $0,1 / 2$ and 1 . The matrix of planning will be obtained by writing the point's coordinates of the simplex lattice (Table 1$)$.

Indices near the properties of the mixture indicate the relative content of each component in the mixture. For example, mixture 1 consists of only the component 1 , the property of this mixture is indicated by $y_{1}$, mixture 4 consists of $1 / 2 X_{1}$ and $1 / 2 X_{2}$, the property is indicated by $y_{12}$.

The coefficients of the polynomial can be figured out, by using the property of the plan saturation. The coefficients of a polynomial can be obtained by

$$
y^{\prime}=\beta_{1} X_{1}+\beta_{2} X_{2}+\beta_{3} X_{3}+\beta_{12} X_{1} X_{2}+\beta_{13} X_{1} X_{3}+\beta_{23} X_{2} X_{3},
$$


sequentially substitution the all six points of the matrix of planning into the equation of coordinate (Table 1$)$. Then, the first point $\left(X_{1}=1, X_{2}=0, X_{3}=0\right)$ will be:

$$
\beta_{1}=y_{1}
$$

Accordingly

$$
\beta_{2}=y_{2} ; \quad \beta_{3}=y_{3} .
$$

After the substituting the other points (Table1) into the equation (1) by considering (2) and (3), the following will be obtained:

$$
\begin{aligned}
& \beta_{13}=4 y_{13}-2\left(y_{1}+y_{3}\right) ; \\
& \beta_{12}=4 y_{12}-2\left(y_{1}+y_{2}\right) ; \\
& \beta_{23}=4 y_{23}-2\left(y_{2}+y_{3}\right) .
\end{aligned}
$$

After finding the coefficients of the regression equation, it is necessary to do a statistical analysis of the obtained results - to check the adequacy of the equation. To verify the equation for adequacy, experiments were carried out in additional, so-called control points.

While studying the "composition-property" diagrams of $q$-component systems, the necessity arises to research the dependence of the property on the composition, not in the whole region of the components' concentration change $0 \leqslant X_{i} \leqslant 1$, but on the local area of the diagram: $0 \leqslant a_{i} \leqslant X_{i} \leqslant b_{i} \leqslant 1, i=$ $1,2, \ldots, q[16]$ (Fig. 1b). The local area of the research on the diagram is an improper simplex, the coordinates of vertices of which $A_{1}\left(X_{1}^{(1)}, X_{2}^{(1)}, \ldots, X_{q}^{(1)}\right), A_{2}\left(X_{1}^{(2)}, X_{2}^{(2)}, \ldots, X_{q}^{(2)}\right), A_{q}\left(X_{1}^{(q)}, X_{2}^{(q)}, \ldots, X_{q}^{(q)}\right)$ are known. For applying the plans, which had used to research the full diagrams, the renormalization was performed and the content in the vertices $A_{i}=(1,2,3)$ was accepted like the independent pseudocomponents $Z_{i}$ in such a way that the condition should be performed for the whole region of the local simplex:

$$
\sum_{i=1}^{q} Z_{i}=1 .
$$

Planning of the experiment is carried out in the coordinate system of pseudo-component. Any plan can be constructed, relatively to the new variables $Z_{1}, Z_{2}, \ldots, Z_{q}$ that satisfy the condition (5). It's necessary to make a transfer from pseudo-component $Z_{i}$ to initial component $X_{i}$. For any $k$-th point of the plan, this transfer is carried out according to the formula:

$$
X_{i}^{(k)}=X_{i}^{(1)}+Z_{2}^{(k)}\left(X_{i}^{(2)}-X_{i}^{(1)}\right)+Z_{3}^{(k)}\left(X_{i}^{(3)}-X_{i}^{(1)}\right)+\ldots+Z_{q}^{(k)}\left(X_{i}^{(q)}-X_{i}^{(1)}\right),
$$

where $X_{i}$ is the content of the $i$-th component in the vertex $Z_{j}\left(A_{j}\right)$.

The coefficients of the regression equation in the coordinates of the pseudo-component can be calculated through the implementation of plan and using the formulas (2)-(4):

$$
y=\left(Z_{1}, Z_{2}, \ldots, Z_{q}\right) \text {. }
$$

For practical use of the equation (6) it should be written in the initial coordinate system by using the transfer coordinates formulas from one affine system to another:

$$
\begin{aligned}
& Z_{1}=Z_{1}^{(1)}+X_{2}\left(Z_{1}^{(2)}-Z_{1}^{(1)}\right)+X_{3}\left(Z_{1}^{(3)}-Z_{1}^{(1)}\right)+\ldots+X_{q}\left(Z_{1}^{(q)}-Z_{1}^{(1)}\right) ; \\
& Z_{2}=Z_{2}^{(1)}+X_{2}\left(Z_{2}^{(2)}-Z_{2}^{(1)}\right)+X_{3}\left(Z_{2}^{(3)}-Z_{2}^{(1)}\right)+\ldots+X_{q}\left(Z_{2}^{(q)}-Z_{2}^{(1)}\right) ; \\
& Z_{q-1}=Z_{q-1}^{(1)}+X_{2}\left(Z_{q-1}^{(2)}-Z_{q-1}^{(1)}\right)+X_{3}\left(Z_{q-1}^{(3)}-Z_{q-1}^{(1)}\right)+\ldots+X_{q}\left(Z_{q-1}^{(q)}-Z_{q-1}^{(1)}\right) .
\end{aligned}
$$


The $Z_{i}^{(j)}$ value can be figured out by solving equations system (8).

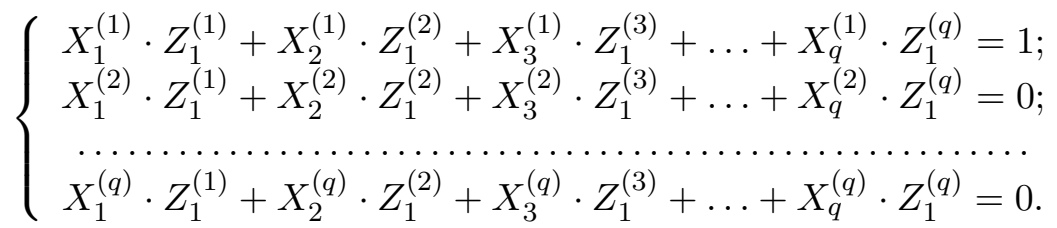

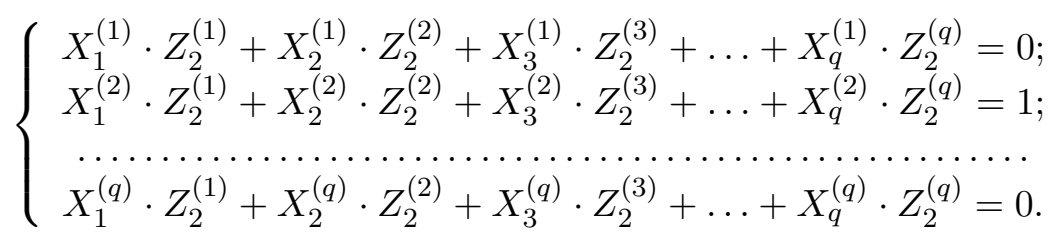

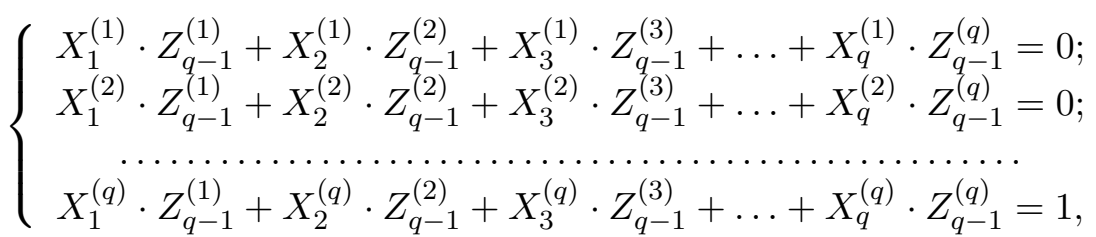

where $Z_{i}^{(i)}$ is the pseudo-component $Z_{i}$ content in the vertices of the initial simplex; $X_{i}^{(j)}$ is the content of the $i$-th component in the vertices $Z_{j}\left(A_{j}\right), j=1,2, \ldots, q$.

Whereas, such a transfer of coordinates is possible only for equations with independent variables, it is necessary to transform the initial regression equation. To do this, one variable should be excluded, for example the last one and write down:

$$
Z_{q}=1-\sum_{i=1}^{q-1} Z_{i}
$$

\section{Results of numerical calculations}

The first stage of the study is to obtain equation-dependences that will be an experimental statistical model of the task and provide the ability to predict the required property for any combination of component content in the PMC.

In our case, not the whole concentration triangle was investigated, but only its local part, which is a simplex with vertices $A_{1}\left(72 \%\right.$ HEMA; $8 \%$ PVP; $\left.20 \% \mathrm{H}_{2} \mathrm{O}\right) ; A_{2}\left(56 \%\right.$ HEMA; $24 \%$ PVP; $\left.20 \% \mathrm{H}_{2} \mathrm{O}\right)$; $A_{3}$ (56\% HEMA; $8 \%$ PVP; $36 \% \mathrm{H}_{2} \mathrm{O}$ ) (Fig. 2).

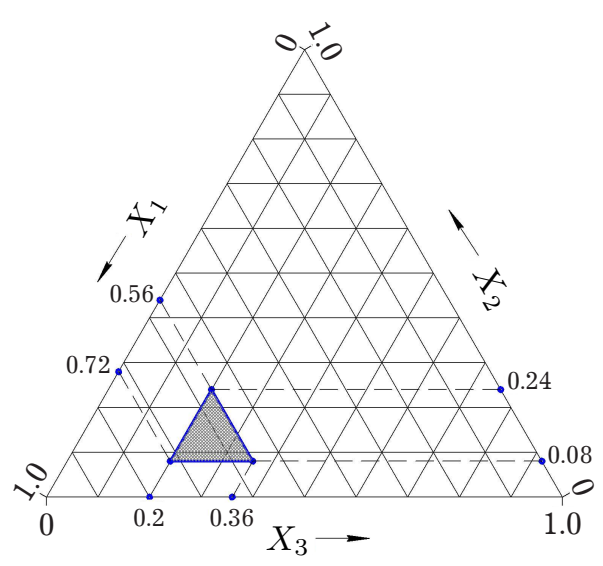

Fig. 2. The field of property research.
Let $X_{1}$ denote the content of HEMA in the original composition, $\% ; X_{2}$ is the content of PVP, $\% ; X_{3}$ is the content of $\mathrm{H}_{2} \mathrm{O}, \%$. The optimization was carried out for exothermic parameters - the start time of the gel formation $\left(\tau_{\text {s.f. }}, \mathrm{min}\right)$, gel-effect area $\left(\tau_{\text {d.e. }}, \mathrm{min}\right)$ and the maximum exothermic temperature $\left(T_{\max },{ }^{\circ} \mathrm{C}\right)$.

In order to obtain the regression equations, the Scheffe's SLP relative to the pseudo-components $Z_{1}, Z_{2}$, $Z_{3}$ should be constructed. To solve the task, the SLP $\{3$, $2\}$ and a second-order polynomial for a triple system (3) were used. In this case, the number of experimental points is 6 .

In Table 2, conditions and results of experiments in the form of pseudo-components and on a natural scale have

Mathematical Modeling and Computing, Vol. 6, No. 2, pp. 258-267 (2019) 
been presented, which were obtained on the basis of the planning matrix (Table 1 ). The average results $y_{1}^{e}\left(T_{\max },{ }^{\circ} \mathrm{C}\right), y_{2}^{e}\left(\tau_{\text {s.f. }}\right.$, $\left.\min \right)$ and $y_{3}^{e}\left(\tau_{\text {d.e. }}, \min \right)$ were obtained by two parallel experiments. Let $y_{1}^{\prime}$ denote the regression equation $T_{\max }, y_{2}^{\prime}$ is the regression equation $\tau_{\text {s.f. }}, y_{3}^{\prime}$ is the regression equation $\tau_{\text {d.e. }}$.

Table 2. Conditions and results of experiments in the form of pseudo-components and on a natural scale.

\begin{tabular}{|c|c|c|c|c|c|c|c|c|c|}
\hline \multirow{2}{*}{ No. } & \multicolumn{2}{|c|}{ Pseudo-components } & \multicolumn{2}{|c|}{ Natural variables } & \multirow{2}{*}{$y_{1}^{e}$} & \multirow{2}{*}{$y_{2}^{e}$} & \multirow{2}{*}{$y_{3}^{e}$} \\
\cline { 2 - 8 } & $Z_{1}$ & $Z_{2}$ & $Z_{3}$ & $X_{1}$ & $X_{2}$ & $X_{3}$ & & & \\
\hline 1 & 1 & 0 & 0 & 0.72 & 0.08 & 0.20 & 103.5 & 23.00 & 37.00 \\
\hline 2 & 0 & 1 & 0 & 0.56 & 0.24 & 0.20 & 84.40 & 13.00 & 18.20 \\
\hline 3 & 0 & 0 & 1 & 0.56 & 0.08 & 0.36 & 79.00 & 24.20 & 36.50 \\
\hline 4 & $1 / 2$ & $1 / 2$ & 0 & 0.64 & 0.16 & 0.20 & 96.80 & 16.00 & 28.00 \\
\hline 5 & $1 / 2$ & 0 & $1 / 2$ & 0.64 & 0.08 & 0.28 & 92.00 & 23.70 & 36.90 \\
\hline 6 & 0 & $1 / 2$ & $1 / 2$ & 0.56 & 0.16 & 0.28 & 84.00 & 17.40 & 26.40 \\
\hline
\end{tabular}

Using the matrix of planning, conditions and results of the experiment (Tables 1,2) and using the property of unsaturated plan [16], the coefficients of the polynomial (1) for $y_{1}^{\prime}, y_{2}^{\prime}$ and $y_{3}^{\prime}$ can be calculated by the equations (2)-(4).

For $y_{1}^{\prime}: \beta_{1}=103.5 ; \beta_{2}=84.4 ; \beta_{3}=79 ; \beta_{12}=11.4 ; \beta_{13}=3 ; \beta_{23}=9.2$

$$
y_{1}^{\prime}=103.5 Z_{1}+84.4 Z_{2}+79 Z_{3}+11.4 Z_{1} Z_{2}+32 Z_{1} Z_{3}+9.2 Z_{2} Z_{3} ;
$$

for $y_{2}^{\prime}: \beta_{1}=23 ; \beta_{2}=13 ; \beta_{3}=24.2 ; \beta_{12}=-8 ; \beta_{13}=0.4 ; \beta_{23}=-4.8$

$$
y_{2}^{\prime}=23 Z_{1}+13 Z_{2}+24.2 Z_{3}-8 Z_{1} Z_{2}+0.4 Z_{1} Z_{3}-4.8 Z_{2} Z_{3}
$$

for $y_{3}^{\prime}: \beta_{1}=37 ; \beta_{2}=18.2 ; \beta_{3}=36.5 ; \beta_{12}=1.6 ; \beta_{13}=0.6 ; \beta_{23}=-3.8$

$$
y_{3}^{\prime}=37 Z_{1}+18.2 Z_{2}+36.5 Z_{3}+1.6 Z_{1} Z_{2}+0.6 Z_{1} Z_{3}-3.8 Z_{2} Z_{3} .
$$

Pseudo-components $Z_{1}, Z_{2}, Z_{3}$ can be calculated, using the formulas of coordinates transfer (7) in the form

$$
\begin{aligned}
& Z_{1}=Z_{1}^{(1)}+X_{2}\left(Z_{1}^{(2)}-Z_{1}^{(1)}\right)+X_{3}\left(Z_{1}^{(3)}-Z_{1}^{(1)}\right) ; \\
& Z_{2}=Z_{2}^{(1)}+X_{2}\left(Z_{2}^{(2)}-Z_{2}^{(1)}\right)+X_{3}\left(Z_{2}^{(3)}-Z_{2}^{(1)}\right) ; \\
& Z_{3}=1-\left(Z_{1}-Z_{2}\right) .
\end{aligned}
$$

For a three-component composition, the system of equations (8) takes the form:

$$
\begin{aligned}
& \left\{\begin{array}{c}
X_{1}^{(1)} \cdot Z_{1}^{(1)}+X_{2}^{(1)} \cdot Z_{1}^{(2)}+X_{3}^{(1)} \cdot Z_{1}^{(3)}=1 ; \\
X_{1}^{(2)} \cdot Z_{1}^{(1)}+X_{2}^{(2)} \cdot Z_{1}^{(2)}+X_{3}^{(2)} \cdot Z_{1}^{(3)}=0 ; \\
X_{1}^{(3)} \cdot Z_{1}^{(1)}+X_{2}^{(3)} \cdot Z_{1}^{(2)}+X_{3}^{(3)} \cdot Z_{1}^{(3)}=0
\end{array}\right. \\
& \left\{\begin{array}{c}
X_{1}^{(1)} \cdot Z_{2}^{(1)}+X_{2}^{(1)} \cdot Z_{2}^{(2)}+X_{3}^{(1)} \cdot Z_{2}^{(3)}=0 ; \\
X_{1}^{(2)} \cdot Z_{2}^{(1)}+X_{2}^{(2)} \cdot Z_{2}^{(2)}+X_{3}^{(2)} \cdot Z_{2}^{(3)}=1 ; \\
X_{1}^{(3)} \cdot Z_{2}^{(1)}+X_{2}^{(3)} \cdot Z_{2}^{(2)}+X_{3}^{(3)} \cdot Z_{2}^{(3)}=0 .
\end{array}\right.
\end{aligned}
$$

Substituting the initial values (Table 2) in the system of equations (13):

$$
\begin{array}{ll}
X_{1}^{(1)}=0.72 ; & X_{2}^{(1)}=0.08 ; \\
X_{1}^{(2)}=0.56 ; & X_{2}^{(2)}=0.24 ; \\
X_{1}^{(3)}=0.56 ; & X_{2}^{(3)}=0.08 .
\end{array}
$$


it is obtaining

$$
\begin{aligned}
& Z_{1}^{(1)}=2.75 ; \quad Z_{1}^{(2)}=-3.5 ; \quad Z_{1}^{(3)}=-3.5 ; \\
& Z_{2}^{(1)}=-0.5 ; \quad Z_{2}^{(2)}=5.75 ; \quad Z_{2}^{(3)}=-0.5 .
\end{aligned}
$$

Using the obtained values of $Z_{i}^{(j)}$ and equation (12), the dependency between the natural coordinates $X_{i}$ and the coordinate system $Z_{i}$ can be figured out:

$$
\begin{aligned}
Z_{1} & =2.75-6.25 X_{2}-6.25 X_{3} \\
X_{2} & =6.25 X_{2}-0.5 \\
Z_{3} & =6.25 X_{3}-1.25
\end{aligned}
$$

Substituting the equation (14) into (9), (10) and (11), the regression equation in the initial coordinates can be obtained

$$
\begin{aligned}
& y_{1}=123.44+63.75 X_{2}-71.25 X_{3}-203.13 X_{2} X_{3}-445.31 X_{2}^{2}-117.19 X_{3}^{2} \\
& y_{2}=33.13-184.38 X_{2}+7.5 X_{3}+109.38 X_{2} X_{3}+312.5 X_{2}^{2}-15.63 X_{3}^{2} \\
& y_{3}=40.39-50.63 X_{2}+28.75 X_{3}-234.38 X_{2} X_{3}-62.5 X_{2}^{2}-23.44 X_{3}^{2} .
\end{aligned}
$$

After determining the coefficients of the regression equations, the adequacy of these equations was checked by Student's criteria $(t)$ in three control points (Table 3). The value of t-ratio was found for each point.

$$
t=\frac{\Delta y \sqrt{n}}{s_{y}^{2} \sqrt{1+\xi}}
$$

where $\Delta y=\left|y^{e}-y^{c}\right| ; y^{e}, y^{c}$ are the properties obtained by the experimental (Table 3) and the calculated (based on the obtained regression equations) methods accordingly; $n$ is the number of parallel experiments at each point $(n=2) ; s_{y}^{2}$ is reproducibility dispersion $\left(s_{y}^{2}\right.$ and $\xi$ were calculated according to the method presented in [15]).

Table 3. Examination the model for adequacy.

\begin{tabular}{|c|c|c|c|c|c|c|c|c|c|c|c|c|c|c|c|}
\hline \multirow{2}{*}{$\begin{array}{c}\text { No. } \\
\text { exp. }\end{array}$} & \multicolumn{2}{|c|}{$\boldsymbol{N}_{1}$ atural variables } & $X_{2}$ & $X_{3}$ & $y_{1}^{c}$ & $\Delta y_{1}$ & $t_{1}$ & $y_{2}^{e}$ & $y_{2}^{c}$ & $\Delta y_{2}$ & \multirow{2}{*}{$t_{2}$} & $y_{3}^{e}$ & $y_{3}^{c}$ & $\Delta y_{3}$ & \multirow{2}{*}{$t_{3}$} \\
\hline 7 & 0.67 & 0.08 & 0.25 & 96.50 & 96.49 & 0.01 & 0.08 & 23.50 & 23.47 & 0.03 & 0.12 & 37.20 & 36.98 & 0.22 & 0.85 \\
\hline 8 & 0.67 & 0.13 & 0.20 & 100.0 & 99.98 & 0.02 & 0.15 & 18.00 & 18.16 & 0.16 & 0.62 & 31.80 & 31.47 & 0.33 & 1.27 \\
\hline 9 & 0.54 & 0.13 & 0.33 & 79.20 & 79.22 & 0.02 & 0.15 & 19.50 & 19.91 & 0.41 & 1.59 & 30.00 & 29.63 & 0.37 & 1.42 \\
\hline
\end{tabular}

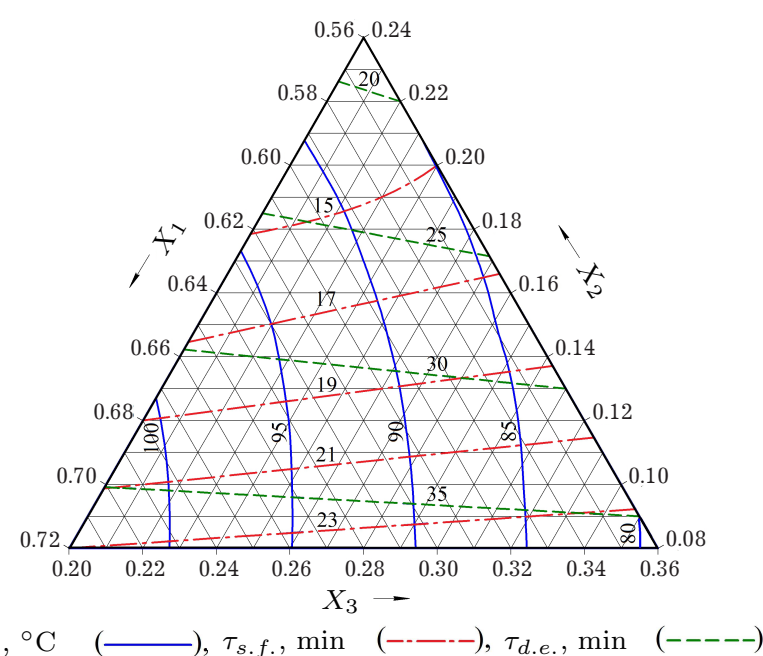

Fig. 3. The lines of the exothermic process equal parameters' values.
For all control points at the level of significance $p=0.05$, the number of degrees of freedom $f_{y}=3$ and $t_{\text {table }}=3.18$ value of the $t$-criterion, in each case, are less than the tabular value (Table 3 ). Therefore, the calculated regression equations are adequate to the experiment and describe the obtained dependences with sufficient accuracy. Equations (15)(17) provide a prediction of the parameters' change character of the exothermic copolymerization HEMA with PVP - a start time of gel formation, a gel-effect area and the maximum exothermic temperature $\left(T_{\max }\right)$ for any formula of the initial composition.

The second research stage is the isolines construction of changing the exothermic parame- 
ters according to the obtained regression equations, depending on each component content of the original composition (Fig. 3).

The obtained lines of equal parameters' values provide a quick search for a totality of values of the components' concentrations in the reaction composition, which make possible to obtain the optimal technological conditions, that are necessary for precipitating the required metal fillers during the polymerization.

\section{Conclusions}

Using the Scheffe's simplex-lattice planning method, the optimization of the experiment was made to forecast the polymerization parameters of HEMA/PVP compositions, which define the technological regime of metals' chemical precipitation. The obtained regression equations are a mathematical modeling result, which allows establishing analytically the relationship of exothermic processes parameters with the technological conditions for the reduction of metal ions, as well as with the formula of the polymer-monomer composition. The obtained lines of equal values of parameters will significantly reduce the experimental search for a composite formula with given parameters of the polymerization process exothermically, depending on the nature of the deposited metal.

[1] Pukach P., Il'kiv V., Nytrebych Z., Vovk M., Pukach P. On the asymptotic methods of the mathematical models of strongly nonlinear physical systems. In: Shakhovska N., Stepashko V. (eds.) Advances in Intelligent Systems and Computing II. CSIT 2017. Advances in Intelligent Systems and Computing. 689, 421-433 (2018).

[2] Pukach P. Investigation of Bending Vibrations in Voigt-Kelvin Bars with Regard for Nonlinear Resistance Forces. Journal of Mathematical Sciences. 215 (1), 71-78 (2016).

[3] Pukach P., Shakhovska K. The mathematical method development of decisions supporting concerning products placement based on analysis of market basket content. 2017 14th International Conference The Experience of Designing and Application of CAD Systems in Microelectronics (CADSM). 347-350 (2017).

[4] Nebesnyi R., Ivasiv V., Pikh Z., Zhyznevskyi V., Dmytruk Yu. The kinetic of the gas phase aldol condensation reaction of propionic acid with formaldehyde on $\mathrm{B}_{2} \mathrm{O}_{3}-\mathrm{P}_{2} \mathrm{O}_{5}-\mathrm{WO}_{3} / \mathrm{SiO}_{2}$ catalyst. Chemistry and Chemical Technology. 8 (1), 29-34 (2014).

[5] Moravskyi V., Dziaman I., Suberliak S., Kuznetsova M., Tsimbalista T., Dulebova L. Research into kinetic patterns of chemical metallization of powderlike polyvinylchloride. Eastern-European Journal of Enterprise Technologies. 4 (12), 50-57 (2017).

[6] Kostrobij P., Ryzha I., Hnativ B. Modeling of the effect of carbon dioxide desorption on carbon monoxide oxidation process on platinum catalyst surface. Mathematical Modeling and Computing. 5 (1), $27-33$ (2018).

[7] Medvedevskikh Y. G., Kytsya A. R., Bazylyak L. I., Turovsky A. A., Zaikov G. E. Stationary and nonstationary kinetics of the photoinitiated polymerization. CRC Press (2004).

[8] Hayvas B., Dmytruk V., Torskyy A., Dmytruk A. On methods of mathematical modeling of drying dispersed materials. Mathematical Modeling and Computing. 4 (2), 139-147 (2017).

[9] Brailo M. V., Buketov A. V., Kobelnyk O.S., Yakushchenko S. V., Sapronova A. V., Sapronov O. O., Vasylenko A. O. Optimization of the content of additives in epoxy-polyester binder to increase the cohesive strength of composites. Scientific Bulletin of UNFU. 28 (11), 71 (2018), (in Ukrainian).

[10] Kostrobij P., Beznosiuk A., Dmytruk V., Polovyi V. Modeling of Pt-catalyst surface influence on characteristics of oxygen and carbon monoxide molecules. Mathematical Modeling and Computing. 3 (1), 43-50 (2016).

[11] Suberlyak O. V., Krasins'kyi V. V., Shapoval I. M., Grytsenko O. M. Influence of the mechanism and parameters of hardening of modified novolac phenol-formaldehyde resins on the physicomechanical properties of the composite. Materials Science. 46 (5), 669-678 (2011).

[12] Baran N. M., Krasinskyy V. V., Zemke V. M., Grytsenko O. M., Burcha T. M. Prohnozuvannya vlastyvostey modyfikovanykh poliamidnykh membran iz zastosuvannyam matematychnoho modelyuvannya skladu 
polimernoyi sumishi. Visnyk Natsionalnoho universytetu "Lvivska politekhnika". 726, 437-443 (2012), (in Ukrainian).

[13] Zaikov G. E., Bazylyak L. I., Aneli J. N. Polymers for Advanced Technologies: Processing, Characterization and Applications. CRC Press, Toronto (2013).

[14] Bogdanova V. V., Kobets O. I., Lyudko A. A., Kirlitsa V. P. Optimizatsiya ognezashchitno-ognetushashchikh svoystv sostava dlya predotvrashcheniya i lokalizatsii pozharov v prirodnom komplekse metodom matematicheskogo planirovaniya eksperimenta. Vestnik Komandno-inzhenernogo instituta MCHS Respubliki Belarus. 1 (15), 32-39 (2012), (in Russian).

[15] Akhnazarova S. L., Kafarov V. V. Metody optimizatsii eksperimenta v khimicheskoy tekhnologii. Moskva, Vysshaya shkola (1985), (in Russian).

[16] Afonin Yu.S., Dubrovin V.I. Modelirovanie sostavov smesej metodom simpleksnyh reshetok. Radioelektronika. Informatyka. Upravlinnya. 2, 60-63 (2004), (in Russian).

[17] Akhmetzhanov A. M., Urbanov A. V., Potapova Ye. N. Primeneniye metodov planirovaniya eksperimenta pri izuchenii kompleksnogo vliyaniya dobavok na svoystva vyazhuchego. Uspekhi v khimii i khimicheskoy tekhnologii. 30 (7), 14-16 (2016), (in Russian).

[18] Hanemann T., Szabo D. V. Polymer-Nanoparticle composites: from synthesis to modern applications. Materials. 3, 3468-3517 (2010).

[19] Hule R. A., Pochan D. J. Polymer Nanocomposites for biomedical applications. MRS. Bulletin. 32, 354-358 (2007).

[20] Moravskyi V., Dziaman I., Suberliak S., Grytsenko O., Kuznetsova M. Features of the production of metalfilled composites by metallization of polymeric raw materials. 2017 IEEE 7th International Conference Nanomaterials: Application \& Properties (NAP). 03NNSA18-1-03NNSA18-4 (2017).

[21] Zare Y., Shabani I. Polymer/metal nanocomposites for biomedical applications. Materials Science and Engineering. 60, 195-203 (2016).

[22] Nicolais L., Carotenuto G. Metal-polymer nanocomposites. New Jersey, John Wiley and Sons (2005).

[23] Suberlyak O., Grytsenko O., Kochubei V. The role of $\mathrm{FeSO}_{4}$ in the obtaining of polyvinylpirolidone copolymers. Chemistry and Chemical Technology. 9, 429-434 (2015).

[24] Schexnailder P., Schmidt G. Nanocomposite polymer hydrogels. Colloid and Polymer Science. 287 (1), 1-11 (2009).

[25] Haraguchi K. Nanocomposite hydrogels. Current Opinion in Solid State and Materials Science. 11 (3-4), 47-54 (2007).

[26] Suberlyak O.V., Hrytsenko O. M., Hishchak K. Y. Influence of the metal surface of powder filler om the structure and properties of composite materials based on the co-polymers of methacrylates with polyvinylpyrrolidone. Materials Science. 52 (2), 155-164 (2016).

[27] Thomas V., Namdeo M., Murali Mohan Y., Bajpai S. K., Bajpai M. Hydrogel and microgel metal nanocomposites: a facile nanotechnological approach. Journal of Macromolecular Science. 45, 107-119 (2007).

[28] Grytsenko O., Suberliak O., Moravskyi V., Gaiduk A. Investigation of nickel chemical precipitation kinetics. Eastern-European Journal of Enterprise Technologies. 1 (6), 26-31 (2016), (in Ukrainian).

[29] Grytsenko O., Gajdos I., Spisak E., Krasinskyi V., Suberlyak O. Novel Ni/pHEMA-gr-PVP Composites Obtained by Polymerization with Simultaneous Metal Deposition: Structure and Properties. Materials. 12 (12), 1956 (2019).

[30] Grytsenko O., Pokhmurska A., Suberliak S., Kushnirchuk M., Panas M., Moravskyi V., Kovalchuk R. Technological features in obtaining highly effective hydrogel dressings for medical purposes. Eastern-European Journal of Enterprise Technologies. 6 (6), 6-13 (2018). 


\title{
Використання методу Шеффе у дослідженні математичної моделі оптимізації композиційних складів полімерних гідрогелів
}

\author{
Гриценко О. М. ${ }^{1}$, Пукач П. Я. ${ }^{1}$, Суберляк О. В. ${ }^{1}$, Моравський В. С. ${ }^{1}$, Ковальчук Р. А. ${ }^{2}$, \\ Бережний Б. В. ${ }^{1}$ \\ ${ }^{1}$ Національний університет “Лъвівсъка політехніка", \\ вул. С. Бандери, 12, Львів, 79013, Україна \\ ${ }^{2}$ Національна академія сухопутних війсък імені гетъмана Петра Сагайдачного, \\ вул. Героїв Майдану, 32, Львів, 79012, Украӥна
}

\begin{abstract}
Методом симплекс-граткового планування Шеффе здійснено математичне моделювання процесу кополімеризації 2-гідроксіетилметакрилату з полівінілпіролідоном за технологічними параметрами екзотермії реакції. Здійснено оптимізацію складу полімер-мономерної композиції та одержано рівняння регресії основних параметрів процесу екзотермії полімеризації - часу початку гелеутворення, тривалості області гель-ефекту, максимальної температури екзотермії. 3 використанням одержаної математичної моделі встановлено вміст вихідної композиції, екзотермічні ефекти процесу полімеризації якої забезпечують оптимальні технологічні параметри стадії відновлення йонів металів під час полімеризації.
\end{abstract}

Ключові слова: математичне моделювання, метод Шеффе симплекс-љраткового планування, оптимізація композиційних складів, металонаповнені гідрогелі, екзотермія.

2000 MSC: 00A71, 62P30

удК: 678.746

Mathematical Modeling and Computing, Vol.6, No. 2, pp. 258-267 (2019) 